\title{
Study of Instructional Management and Insti- tutional EfFectiveness in Relation to Age AND EXPERIENCE O F SCHOOL PRINCIPALS
}

\author{
Deepa Sikand Kauts $(\mathbb{D}$, Amit Kauts $(\mathbb{D}$ and Supriya Dang $(\mathbb{1}$
}

The present investigation intends to assess instructional management and institutional effectiveness concerning the age and experience of school principals. The sample comprised twenty schools of Jalandhar and Kapurthala. The researchers used Hallinger's Instructional Management Rating Scale and a self-prepared Institutional Effectiveness Rating Scale for the investigation. The result of the study reveals that in schools with younger principals, teachers exhibit better behaviour on coordinating the curriculum, protecting instruction time and developing academic standards of instructional management than teachers in schools with older principals. In schools with more experienced principals, teachers exhibit better behaviour concerning instructional management, protecting instruction time, providing incentives for teachers, etc. than the teachers in schools with less experience. In schools with older and more experienced principals, teachers exhibit better behaviour on supervising and evaluating instruction dimension of instructional leadership than the teachers in schools with older and less experience, younger and more experienced and younger and less experienced principals. There is no significant difference in the institutional effectiveness of schools with young and old aged principals. There is no significant difference in institutional effectiveness of schools with more and less experienced principals.

KEYWORDS: Instructional Management, Institutional Effectiveness, Age and Experience

Deepa Sikand Kauts $\square$

Department of Education, Guru Nanak Dev University, Amritsar, India.

Email: kdeepasikand@gmail.com. ORCID: https://orcid.org/0000-0001-8661-465X

Amit Kauts

Department of Education, Guru Nanak Dev University, Amritsar, India.

Email: amitkauts@yahoo.com. ORCID: https://orcid.org/0000-0003-1150-6384

Supriya Dang

Institute of Law and Research,, Faridabad, India.

Email: supryabhandari24@yahoo.com. ORCID: https://orcid.org/0000-0002-5719-6177 


\section{INTRODUCTION}

Education plays a key role for human and cultural development. It contributes to human development together with environmental and character influences. Today education system faces several challenges such as the scarcity of resources, the introduction of new technologies and the growing multiculturalism of students. Referring to the education system, school leadership has registered a systematic decentralization of functions. Common sense observation reveals that schools are rarely effective in any sense of the world, unless the principal or the head is a good leader or a good organizer. The principal is the co-ordinating agency which keeps the balance and ensures the harmonious development of the whole institution. Principal wears many hats being manager, administrator, instructional leader and curriculum leader at different points in a day. The role of 'instructional leader' by school leader is relatively a new concept that emerged in the early 1980's which called for a shift of emphasis from principals being managers or administrators to instructional or academic leaders. The shift was influenced largely by research which found that effective schools usually had principals who stressed the importance of instructional leadership (Brookover \& Legotte, 1982). New governance system means that new leadership is able to negotiate decisions and build network relations (Pedersen \& Hartley, 2008). Leadership impacts also on job satisfaction and may indirectly affect students via teacher selection and motivation, and control over the curriculum (Cerit, 2009). Recently instructional leadership has made a comeback with increasing place on academic standards and the need for schools to be accountable.

\section{InStRUCTIONAL MANAGEMENT}

Instructional Management refers to demonstrating a pattern of expert practice in classroom. This includes two broad components of teaching skill: (1) expertise in planning for instruction and (2) expertise in delivering instruction. Before teaching a lesson, successful teachers make important planning decisions about their goals and objectives. These goals and objectives give learners a purpose or reason for the activities they were pursuing. They also made it easier to gauge the learners' progress. Finally, successful teachers and their learners are able to achieve their goals and objectives because of expert patterns of practice in delivering instruction. The Instructional Management System is designed to help the teacher monitor the progress of her pupils and make decisions on the pace of instruction, the grouping of children, the sequence of lessons and the individualization of instruction. It provides a framework for making decisions on classroom management at any grade level, but some one level must be selected for initial development and demonstration. 
Instructional management is the process of empowering all educational resources to achieve learning objectives. Operational instructional management is the implementation of management functions on learning components, namely: students, teachers, goals, materials, methods, tools, and evaluation (Rahayu, 2015). Instructional management is an activity to plan teaching and learning programs, implement teaching and learning process, and assess the process and learning outcomes, and the develop of classroom management (Danarwati, 2016).

Instructional management is a series of activities: (1) instructional plan, is syllabus, lesson plan, and teaching materials; (2) instructional implementation, encompassing methodology and instructional design; and (3) assessment of learning, concerning lattice, grain verification, and assessment aspect (Widodo, 2016; Gunawan, 2014). The teachers approach to instructional management sets the tone for the overall classroom atmosphere and ultimately student behaviour stressors (Martin, et al., 2012). Instructional management includes student control, instructional style, setting rules, and the regulation of student misbehaviours (Sass, Lopes, Oliveira, \& Martin, 2016). Instructional design and resources have been made to include scaffolding learner participation in a discussion forum (Gasevic, Mirriahi, Dawson, \& Joksimovic, 2016). Stated differently, what a teacher believes is the best behaviour and instructional management style may not be realized depending on the class environment (Martin \& Sass, 2010). Personal factors such as professional commitment proved to be important trait for an effective instructional management (Khan, 2012).

\section{INSTITUTIONAL EFFECTIVENESS}

An effective institution is the one which promotes in a lasting way the progress for all its pupils above and beyond what would be expected, given consideration of their initial attainment and their situation upon entry. Such an institution likewise ensures that each pupil achieves the highest standard possible and enhances an aspect of students' achievement and development. Institutional effectiveness involves not only assessment but also objectives, collaboration, purposeful review, and engagement of constituent stakeholders. It is an important part of any healthy organization. It generates data, which inform strategic plans for programme development and improvement. Different departments must develop their own objectives, criteria and means of measuring outcomes.

In the literature, considerable attention has been devoted to teachers' roles in the improvement of school effectiveness, but it also includes a large body of information about leadership skills and knowledge that principals require for supporting and improving education (Southworth, 2002). 
Specifically, comparisons of effective and ineffective schools have begun to identify factors that promote higher student achievement, particularly in the basic skills. Erlendsson (2002) defined effectiveness as the extent to which objectives are met ('doing the right things'). Educational effectiveness creates a value-added process through quality assurance and accreditation review and contributes to building, within the institution, a culture of evidence. (Vlasceanu, Grunberg, \& Parlea, 2004). Anumaka (2013)conducted a study titled "Institutional Effectiveness: Best Practices and Assessment Strategies in Uganda Universities." The study was conducted to know about the measures of effectiveness of higher education namely using data to measure students learning outcomes, and institutional support services in terms of teaching, research, and community support services. Findings revealed that Uganda's universities relegate data usage to a very minimal relevance in terms of support in teaching, research, community services and in many areas that contribute to effectiveness of higher education. Saleem (2012) conducted a study titled "Determinants of School Effectiveness: A Study at Punjab Level." The aim of this study was to find out the determinants of school effectiveness in Pakistani context. A questionnaire was developed based on the opinions of experts and educationists about the determinants of effective schools. The questionnaire consisted of 17 determinants of school effectiveness having 68 items. The analysis of the data revealed that all the variables were strongly interrelated with each other. One study by Huber (2013) revealed 30 dimensions in the study of the profiles of school leaders that contribute to school effectiveness. These 30 dimensions included general skills as well as engagement, self-efficacy, ambiguity tolerance, empathy, and enthusiasm to name a few. A self-reflection of leaders according to these dimensions promotes contemplation and with this "promotes the motivation to gather more information about their behaviour in day-to-day practice."

Taiwo (2015) carried out a study titled "Teacher Variables and School Effectiveness" in Ekiti state, Nigeria. It was found that majority of secondary school teachers in Ekiti State were professionally qualified. The ratio of teacher to students was also within acceptable range, but their teachings were not effective. Majority of qualified teachers were teaching in urban/city schools. There were significant differences in the effectiveness of (i) urban and rural teachers (ii) male and female teachers (iii) arts, science, and Business education teachers. Alm, Laftman, Sandahl, and Modin (2019) school environment contributes to shaping students' beliefs about their future. Thus, enhancing features of school effectiveness may be a way of promoting a positive development and brighter objective prospects for the young, via pathways such as good studentteacher relations and academic motivation and achievement. 


\section{ObJectives of the Study}

The present study is designed to attain the following objectives:

1) To study instructional management in relation to age and experience of school principals.

2) To study institutional effectiveness in relation to age and experience of school principals.

\section{SAMPLE OF THE STUdY}

Descriptive method of research was used in the conduct of study. In the present study, twenty CBSE affiliated schools were identified from Jalandhar and Kapurthala Division. On the basis of age and experience of principals, 10 schools with more experience (more than 8 years) and 10 schools with less experience (less than 5 years) were identified, out of which 4 schools with more age (above 50) and 6 with less age (less than 45) principals were identified from each group i.e., schools with more experience and less experience principals. Finally, 15 teachers were selected randomly from each school. The data for the present investigation was collected using the following tool:

1) Hallinger's Instructional Management Rating Scale

2) Institutional Effectiveness Rating Scale prepared by the investigators.

\section{RESULTS AND INTERPRETATIONS}

The data obtained have been analysed under the following headings:

1) $2 \times 2$ analysis of variance on the scores of various dimensions of instructional management.

2) Significance of difference between institutional effectiveness and age of school principals on the scores of institutional effectiveness

3) Significance of difference between institutional effectiveness and experience of school principals on the scores of institutional effectiveness

\section{I) $2 \times 2$ Analysis of Variance on the Scores of Various Dimensions of Instructional Management}

The means of subgroups of $2 \times 2$ design of ANOVA for different dimensions of instructional management have been calculated and presented in Table 1 
Study of Instructional Management | 334

Table 1

Means and Standard Deviations for $2 \times 2$ Analysis of Variance on the Scores of Various Dimensions of Instructional Management.

\begin{tabular}{|c|c|c|c|c|c|}
\hline Dimensions & $\begin{array}{l}\text { Level of Experi- } \\
\text { ence }\end{array}$ & $\begin{array}{l}\text { Principals } \\
\text { with More } \\
\text { Age }\end{array}$ & $\begin{array}{l}\text { Principals } \\
\text { with Less } \\
\text { Age }\end{array}$ & & \\
\hline Framing & Principals & $\mathrm{M}_{1}=35.51$ & $\mathrm{M}_{2}=34.82$ & $\mathrm{MM}_{1}$ & $=$ \\
\hline School Goals & with More & $\sigma_{1}=4.73$ & $\sigma_{2}=5.34$ & 35.19 & \\
\hline (I) & Experience. & $\mathrm{N}_{1}=60$ & $\mathrm{~N}_{2}=90$ & & \\
\hline & Principals with & $\mathrm{M}_{3}=31.18$ & $M_{4}=33.26$ & $\mathrm{MM}_{2}$ & $=$ \\
\hline & Less Experience & $\sigma_{3}=5.47$ & $\sigma_{4}=3.54$ & 32.22 & \\
\hline & & $\begin{array}{l}\mathrm{N}_{3}=60 \\
\mathrm{MM}_{3} \\
33.37\end{array}=$ & $\begin{array}{l}\mathrm{N}_{4}=90 \\
\mathrm{MM}_{4} \\
34.04\end{array}$ & & \\
\hline \multirow{6}{*}{$\begin{array}{l}\text { Supervising } \\
\text { and Evaluating } \\
\text { Instructions } \\
\text { (II) }\end{array}$} & M.E. & $\mathrm{M}_{1}=34.1$ & $M_{2}=32.16$ & $\mathrm{MM}_{1}$ & $=$ \\
\hline & & $\sigma_{1}=3.91$ & $\sigma_{2}=5.27$ & 33.13 & \\
\hline & & $\mathrm{N}_{1}=60$ & $\mathrm{~N}_{2}=90$ & & \\
\hline & L.E. & $\mathrm{M}_{3}=31.28$ & $\mathrm{M}_{4}=32.3 \sigma_{4}$ & $\mathrm{MM}_{2}$ & $=$ \\
\hline & & $\begin{array}{l}\sigma_{3}=5.04 \\
\mathrm{~N}_{3}=60\end{array}$ & $\begin{array}{l}=5.50 \mathrm{~N}_{4}= \\
90\end{array}$ & 31.79 & \\
\hline & & $\begin{array}{l}\mathrm{MM}_{3}= \\
32.69\end{array}$ & $\begin{array}{l}\mathrm{MM}_{4} \\
32.23\end{array}$ & & \\
\hline \multirow{7}{*}{$\begin{array}{l}\text { Co-Ordinating } \\
\text { the } \\
\text { Curriculum } \\
\text { (III) }\end{array}$} & M.E. & $\mathrm{M}_{1}=25.01$ & $\mathrm{M}_{2}=26.32$ & $\mathrm{MM}_{1}$ & $=$ \\
\hline & & $\sigma_{1}=3.41$ & $\sigma_{2}=3.46$ & 25.66 & \\
\hline & & $\mathrm{N}_{1}=60$ & $\mathrm{~N}_{2}=90$ & & \\
\hline & L.E. & $\mathrm{M}_{3}=23.18$ & $\mathrm{M}_{4}=24.76$ & $\mathrm{MM}_{2}$ & $=$ \\
\hline & & $\sigma_{3}=5.74$ & $\sigma_{4}=3.55$ & 23.97 & \\
\hline & & $\mathrm{N}_{3}=60$ & $\mathrm{~N}_{4}=90$ & & \\
\hline & & $\begin{array}{l}\mathrm{MM}_{3} \\
24.09\end{array}=$ & $\begin{array}{l}\mathrm{MM}_{4} \\
25.54\end{array}$ & & \\
\hline \multirow{5}{*}{$\begin{array}{l}\text { Monitoring } \\
\text { students } \\
\text { performance } \\
\text { (IV) }\end{array}$} & M.E. & $M_{1}=26.68$ & $\mathrm{M}_{2}=28.35$ & $\mathrm{MM}_{1}$ & $=$ \\
\hline & & $\sigma_{1}=4.38$ & $\sigma_{2}=6.57$ & 27.51 & \\
\hline & & $\mathrm{N}_{1}=60$ & $\mathrm{~N}_{2}=90$ & & \\
\hline & L.E. & $\mathrm{M}_{3}=24.36$ & $\mathrm{M}_{4}=25.1 \sigma_{4}$ & $\mathrm{MM}_{2}$ & $=$ \\
\hline & & $\begin{array}{l}\sigma_{3}=6.94 \\
\mathrm{~N}_{3}=60\end{array}$ & $\begin{array}{l}=5.07 \mathrm{~N}_{4}= \\
90\end{array}$ & 24.73 & \\
\hline
\end{tabular}




\begin{tabular}{|c|c|c|c|c|c|}
\hline & & $\begin{array}{l}\mathrm{MM}_{3} \\
25.52\end{array}$ & $\begin{array}{l}\mathrm{MM}_{4} \\
26.72\end{array}$ & & \\
\hline \multirow{8}{*}{$\begin{array}{l}\text { Protecting } \\
\text { instruction } \\
\text { time }(\mathrm{V})\end{array}$} & M.E. & $\mathrm{M}_{1}=13.43$ & $\mathrm{M}_{2}=14.88$ & $\mathrm{MM}_{1}$ & $=$ \\
\hline & & $\sigma_{1}=4.20$ & $\sigma_{2}=2.46$ & 14.15 & \\
\hline & & $\mathrm{N}_{1}=60$ & $\mathrm{~N}_{2}=90$ & & \\
\hline & L.E. & $\mathrm{M}_{3}=12.85$ & $\mathrm{M}_{4}=14.12$ & $\mathrm{MM}_{2}$ & $=$ \\
\hline & & $\sigma_{3}=3.37$ & $\sigma_{4}=1.9 \mathrm{~N}_{4}$ & 13.48 & \\
\hline & & $\mathrm{N}_{3}=60$ & $=90$ & & \\
\hline & & $\mathrm{MM}_{3}$ & $\mathrm{MM}_{4}=14.5$ & & \\
\hline & & 13.14 & & & \\
\hline \multirow{8}{*}{$\begin{array}{l}\text { Maintaining } \\
\text { administration } \\
\text { visibility }(\mathrm{VI})\end{array}$} & M.E. & $\mathrm{M}_{1}=17.48$ & $\mathrm{M}_{2}=18.34$ & $\mathrm{MM}_{1}$ & $=$ \\
\hline & & $\sigma_{1}=0.98$ & $\sigma_{2}=8.09$ & 17.91 & \\
\hline & & $\mathrm{N}_{1}=60$ & $\mathrm{~N}_{2}=90$ & & \\
\hline & L.E. & $\mathrm{M}_{3}=14.5$ & $\mathrm{M}_{4}=12.54$ & $\mathrm{MM}_{2}$ & $=$ \\
\hline & & $\sigma_{3}=7.56$ & $\sigma_{4}=1.70$ & 13.52 & \\
\hline & & $\mathrm{N}_{3}=60$ & $\mathrm{~N}_{4}=90$ & & \\
\hline & & $\mathrm{MM}_{3}$ & $\mathrm{MM}_{4}$ & & \\
\hline & & 15.99 & 15.44 & & \\
\hline \multirow{8}{*}{$\begin{array}{l}\text { Providing } \\
\text { incentives for } \\
\text { teachers (VII) }\end{array}$} & M.E. & $\mathrm{M}_{1}=12.1$ & $\mathrm{M}_{2}=14.2 \sigma_{2}$ & $\mathrm{MM}_{1}$ & $=$ \\
\hline & & $\sigma_{1}=1.49$ & $=2.4 \mathrm{~N}_{2}=$ & 13.15 & \\
\hline & & $\mathrm{N}_{1}=60$ & 90 & & \\
\hline & L.E. & $\mathrm{M}_{3}=10.96$ & $\mathrm{M}_{4}=11.3 \sigma_{4}$ & $\mathrm{MM}_{2}$ & $=$ \\
\hline & & $\sigma_{3}=1.02$ & $=2.64 \mathrm{~N}_{4}=$ & 11.13 & \\
\hline & & $\mathrm{N}_{3}=60$ & 90 & & \\
\hline & & $\mathrm{MM}_{3}$ & $\mathrm{MM}_{4}$ & & \\
\hline & & 11.53 & 12.75 & & \\
\hline \multirow{6}{*}{$\begin{array}{l}\text { Protecting } \\
\text { professional } \\
\text { development } \\
\text { (VIII) }\end{array}$} & M.E. & $\mathrm{M}_{1}=27.8$ & $\mathrm{M}_{2}=32.6 \sigma_{2}$ & $\mathrm{MM}_{1}$ & $=$ \\
\hline & & $\sigma_{1}=4.2 \mathrm{~N}_{1}$ & $=5.34 \mathrm{~N}_{2}=$ & 30.18 & \\
\hline & L.E. & $M_{3}=26.68$ & $\mathrm{M}_{4}=26.5 \sigma_{4}$ & $\mathrm{MM}_{2}$ & $=$ \\
\hline & & $\begin{array}{l}\sigma_{3}=3.5 \mathrm{~N}_{3} \\
=60\end{array}$ & $\begin{array}{l}=3.56 \mathrm{~N}_{4}= \\
90\end{array}$ & 26.59 & \\
\hline & & $\mathrm{MM}_{3}$ & $\mathrm{MM}_{4}$ & & \\
\hline & & 27.24 & 29.53 & & \\
\hline \multirow{3}{*}{$\begin{array}{l}\text { Developing } \\
\text { academic } \\
\text { standards (IX) }\end{array}$} & M.E. & $\mathrm{M}_{1}=13.71$ & $M_{2}=15.93$ & $\mathrm{MM}_{1}$ & $=$ \\
\hline & & $\sigma_{1}=3.31$ & $\sigma_{2}=2.38$ & 14.82 & \\
\hline & & $\mathrm{N}_{1}=60$ & $\mathrm{~N}_{2}=90$ & & \\
\hline
\end{tabular}


Table 1 continued

\begin{tabular}{lllll}
\hline & L.E. & $\mathrm{M}_{3}=12.8$ & $\mathrm{M}_{4}=14.32$ & $\mathrm{MM}_{2}=$ \\
& & $\sigma_{3}=4.10$ & $\sigma_{4}=1.04$ & 13.56 \\
& $\mathrm{~N}_{3}=60$ & $\mathrm{~N}_{4}=90$ & \\
& $\mathrm{MM}_{3}=$ & $\mathrm{MM}_{4}=$ & \\
& & 13.25 & 15.12 & \\
& & $\mathrm{M}_{1}=10.28$ & $\mathrm{M}_{2}=10.01$ & $\mathrm{MM}_{1}=$ \\
& & $\sigma_{1}=1.53$ & $\sigma_{2}=1.88$ & 10.14 \\
Providing & M.E. & $\mathrm{N}_{1}=60$ & $\mathrm{~N}_{2}=90$ & \\
Incentives for & & $\mathrm{M}_{3}=9.54$ & $\mathrm{M}_{4}=9.84 \sigma_{4}$ & $\mathrm{MM}_{2}=$ \\
learning $(X)$ & & $\sigma_{3}=1.15$ & $=1.26 \mathrm{~N}_{4}=$ & 9.63 \\
& L.E. & & $\mathrm{N}_{3}=60$ & 90 \\
& $\mathrm{MM}_{3}=$ & $\mathrm{MM}_{4}=9.92$ & \\
& 9.85 & & \\
& &
\end{tabular}

To analyse the variance of various dimensions of instructional management of the obtained scores ANOVA was calculated and the results have been presented in Table 2.

\section{Table 2}

Summary of ANOVA for 2 X 2 Design in Respect of Various Dimensions of Instructional Management.

\begin{tabular}{|c|c|c|c|c|c|c|}
\hline \multirow{2}{*}{$\begin{array}{l}\text { S.No. } \\
1\end{array}$} & Dimensions & \multirow{2}{*}{$\begin{array}{l}\text { MSS } \\
\text { MSS }\end{array}$} & \multirow{2}{*}{$\begin{array}{l}\text { Age } \\
34.72\end{array}$} & \multicolumn{3}{|c|}{ ExperienceInteraction Within } \\
\hline & $\begin{array}{l}\text { Framing School } \\
\text { Goals }\end{array}$ & & & 533.33 & 138.88 & 1077.72 \\
\hline & & $\mathrm{F}$ & 0.03 & 0.049 & 0.128 & \\
\hline 2 & $\begin{array}{l}\text { Supervising } \\
\text { and Evaluating } \\
\text { Instruction }\end{array}$ & MSS & 13.68 & 78.03 & 161.39 & 26.31 \\
\hline & & $\mathrm{F}$ & 0.52 & 2.97 & $6.134^{*}$ & \\
\hline 3 & $\begin{array}{l}\text { Co-Ordinating } \\
\text { the Curriculum }\end{array}$ & MSS & 150.22 & 208.33 & 1.38 & 9.009 \\
\hline & & $\mathrm{F}$ & $16.67^{* *}$ & $23.12^{* *}$ & 0.153 & \\
\hline 4 & $\begin{array}{l}\text { Monitoring } \\
\text { Students } \\
\text { Performance }\end{array}$ & MSS & 104.15 & 622.07 & 15.87 & 24497.4 \\
\hline 5 & $\begin{array}{l}\text { Protecting } \\
\text { Instructions } \\
\text { Time }\end{array}$ & $\begin{array}{c}\text { F } \\
\text { MSS }\end{array}$ & $\begin{array}{l}0.004 \\
133.92\end{array}$ & $\begin{array}{c}0.0025 \\
36.04\end{array}$ & $\begin{array}{c}0.0006 \\
0.62\end{array}$ & 8.95 \\
\hline
\end{tabular}




\begin{tabular}{|c|c|c|c|c|c|c|}
\hline \multicolumn{7}{|c|}{ Table 2 continued } \\
\hline & & $\mathrm{F}$ & $14.9^{* *}$ & $4.02 *$ & 0.06 & \\
\hline \multirow[t]{4}{*}{6} & Maintaining & MSS & 274.55 & 210 & 85.8 & 3308.44 \\
\hline & Administrative & & & & & \\
\hline & Visibilities & & & & & \\
\hline & & $\mathrm{F}$ & 0.0008 & 0.0006 & 0.00025 & \\
\hline \multirow[t]{2}{*}{7} & Providing Incen- & MSS & 104.15 & 369.62 & 50.34 & 42.63 \\
\hline & & $\mathrm{F}$ & 2.44 & $8.67^{*}$ & 1.18 & \\
\hline \multirow[t]{4}{*}{8} & Protecting & MSS & 27.12 & 322.39 & 45.78 & 18.88 \\
\hline & Professional & & & & & \\
\hline & Development & & & & & \\
\hline & & $\mathrm{F}$ & 1.43 & $17.07^{* *}$ & 2.42 & \\
\hline \multirow[t]{2}{*}{9} & Developing Aca- & MSS & 251.61 & 133.32 & 8.7 & 7.82 \\
\hline & & $\mathrm{F}$ & $32.17^{* *}$ & $17.04^{* *}$ & 1.11 & \\
\hline \multirow[t]{2}{*}{10} & Providing Incen- & MSS & 0.33 & 14.52 & 8.4 & 3.701 \\
\hline & & $\mathrm{F}$ & 0.089 & $3.92 *$ & 2.26 & \\
\hline
\end{tabular}

$\mathrm{df}$ of variances $=1, \mathrm{df}$ of within $=292 * *$ Significant at 0.01 level $*$ Significant at 0.05 level

\section{Age (A)}

It may be observed from the Table 2 that the F- ratio for the difference between means of teachers in schools with more age and less age principals on the scores of dimensions III, IV and IX of instructional management i.e., 'co-ordinating the curriculum', 'protecting instruction time' and "developing academic standards" have been found to be significant either at 0.01 or 0.5 level of confidence. Further, means Table 1 suggest that principals in lower age group coordinate the curriculum, protects the instructional time and sets academic standards better than principals in higher age group.

\section{Experience (B)}

It may be observed from the Table 2 that the F-ratios for the difference between means of Teachers in schools with more experience and less experience principals on the scores of dimensions III, V, VII, VIII, IX and X i.e. 'co-ordinating the curriculum', 'protecting instruction time', 'providing incentives for teachers', 'protecting professional development', 'develop academic standards' and 'providing incentives for learning' have been found to be significant either at 0.05 or 0.01 level of confidence. Further, Means Table 1 suggest that principals with more experience coordinate the curriculum, protects the instructional time, providing incentives for teachers, sets academic standards and providing incentives for learning better than principals with less experi- 
ence.

\section{Age and Experience Interaction (AXB)}

It may be observed from Table 2 that the F-ratio for the interaction between age and experience on the dimension II i.e., 'supervising and evaluative instruction' has been found to be significant at 0.05 level of significance.

To identify the difference of means of various cells of $2 \times 2$ design due to which F-ratios for the interaction between age and experience have been found significant, t-ratios have been calculated and are recorded in the Table 3.

Table 3

t-Ratios for the Difference in Means of Various Cells of 2 X 2 Design.

\begin{tabular}{lcccccc}
\hline Dimension & $\mathbf{M}_{1} \mathbf{M}_{2}$ & $\mathbf{M}_{1} \mathbf{M}_{3}$ & $\mathbf{M}_{1} \mathbf{M}_{4}$ & $\mathbf{M}_{2} \mathbf{M}_{3}$ & $\mathbf{M}_{2} \mathbf{M}_{4}$ & $\mathbf{M}_{3} \mathbf{M}_{4}$ \\
\hline t-Ratios & $2.62^{* *}$ & $3.91^{* *}$ & $2.36^{* *}$ & 0.09 & 0.17 & 1.17 \\
\hline
\end{tabular}

* Significant at 0.05 level ** Significant at 0.01 level

Table 3 reveals that the $t$-ratios of the sub groups $M_{1} M_{2}, M_{1} M_{3}$ and $M_{1} M_{4}$ are significant at 0.01 level of significance in case of 'supervising and evaluating instruction' dimension of instructional management. The means Table 1 suggests that principals with more experience and more age exhibit better supervision and evaluation of instruction than principals with more experience and less age, principals with less experience and more age and principals with less experience and less age.

II) Significance of Difference in Institutional Effectiveness Between School Principals with More and Less Age

The means of subgroups in respect of institutional effectiveness scale have been calculated and presented in Table 4.

\section{Table 4}

Means and Standard Deviations for Significance of Difference on the Scores of Institutional Effectiveness.

\begin{tabular}{ll}
\hline MORE AGE PRINCIPALS & LESS AGE PRINCIPALS \\
\hline $\mathrm{M}_{1}=219.62 \sigma_{1}=49.57 \mathrm{~N}_{1}=8$ & $\mathrm{M}_{2}=225.41 \sigma_{2}=50.6 \mathrm{~N}_{2}=12$ \\
\hline
\end{tabular}

To identify the difference of means of institutional effectiveness in respect of age of school principals, t-ratio has been calculated and is recorded in Table 5.

It may be observed from the Table 5 that the t-ratios of the sub group $M_{1} M_{2}$ 
Table 5

t-Ratios for The Difference in Means of Institutional Effectiveness.

\begin{tabular}{|c|c|c|c|}
\hline & & $\sigma_{\mathbf{D}}$ & t-ratio $\mathbf{M}_{1} \mathbf{M}_{2}$ \\
\hline $\begin{array}{l}\text { More Age Principals } \\
\text { Less Age Principals }\end{array}$ & 5.79 & 37.73 & 0.21 \\
\hline
\end{tabular}

is not significant at the 0.05 level of confidence. Hence, age of principals has no impact on institutional effectiveness.

\section{Significance of Difference in Institutional Effectiveness Between School With More and Less Experienced Principal}

The means of subgroups in respect of institutional effectiveness scale have been calculated and presented below in the Table 6 .

Table 6

Means and Standard Deviations for Significance of Difference on the Scores of Institutional Effectiveness Scores.

\begin{tabular}{ll}
\hline MORE AGE PRINCIPALS & LESS AGE PRINCIPALS \\
\hline $\mathrm{M}_{3}=227.6 \sigma_{3}=48.73 \mathrm{~N}_{3}=10$ & $\mathrm{M}_{4}=218.6 \sigma_{4}=52.9 \mathrm{~N}_{4}=10$ \\
\hline
\end{tabular}

To identify the difference of means of institutional effectiveness in respect of experience of school principals, t-ratio has been calculated and is recorded in the Table 1.7 below:

Table 7

t-Ratios for The Difference in Means of Institutional Effectiveness .

\begin{tabular}{lccc}
\hline & $\mathbf{D}$ & $\sigma_{\mathbf{D}}$ & t-ratio $\mathbf{M}_{3} \mathbf{M}_{4}$ \\
\hline $\begin{array}{l}\text { More Experience Principals } \\
\text { Less Experience Principals }\end{array}$ & 9 & 33.34 & 0.38 \\
\hline
\end{tabular}

It may be observed from Table 7 that the $t$-Ratios of the sub group $\mathrm{M}_{3} \mathrm{M}_{4}$ is not significant at the 0.05 level of confidence. Hence, experience of principals has no impact on institutional effectiveness. 


\section{DiscUSSION ON FINDINGS}

The result of the study reveals that in schools with younger principals, teachers score more on co-ordinating the curriculum, protecting instruction time and develop academic standards dimension of instructional leadership than teachers in schools with older principals. In schools with more experienced principals, teachers score more on co-ordinating the curriculum, protecting instruction time, providing incentives for teachers, protecting professional development, and developing academic standards. The above findings are in tune with Hill (2002) investigating in the study that novice principals perceived situations differently than did their expert counterparts. When novice principals thought about their strategies in a meta cognitive format, they did so after a disruptive incident rather than before or during the incident. They often chose to wait to address problems rather than confront and resolve them. Sahu (2002) conducted a study and found that there is a significant difference in the different age groups of heads as regard their role performance and as perceived by teachers. It was found that teachers' perception on evaluation and motivator role of heads differed significantly between 30 years and 30 to 50 years and between 30 to 50 years and 50 years age groups. Mentor and reconciliatory role of heads as perceived by teachers, the significant difference came between 30 years and 30 to 50 years. Bridge building with the community, office manager and planner role of heads as perceived by teachers differed significantly between 30 years and 30 to 50 years.

In schools with more experienced principals perceived that the principals with more experience are more efficient in co-ordinating the curriculum, protecting instruction time, providing incentives for teachers, protecting professional development, developing academic standard and provide instructions for learning than the principals with less experience. The above findings are in tune with Gupton (2003) investigating in the study that expert principals began with an encompassing vision that extended beyond particular staff meetings or sudden encounters with an unforeseen problem. They were more likely to have articulated their vision to staff members at different levels in the organization. These principals also tended to be more inclusive in their thinking and to find ways to translate implicit thinking into their actions. Expert principals were less likely to feel stressed during potentially hostile situations. They engaged in more if-then thinking than did novice principals and were not stymied by perceived roadblocks to their intended course of action. Eraut (2000) found that more experienced principals seemed to possess a greater understanding of the social demands and repercussions of their actions. Their solutions were more collegial than those of novice principals and showed a thorough understanding of each of the subgroups or stakeholders involved in the problem. Novice principals knew that they were different from those they 
led, but they did not know how to effectively use those differences in social class or position. In schools with more age and more experienced principals perceived that principals with more age and more experience were more efficient in supervising and evaluative instructions than the principals with less age and less experience.

The above findings are in tune with Hanushek et al (2008) who suggested that school performance models include student characteristics and school characteristics, principal and school fixed effects and principal experience and tenure. Their interest is in the relationship between principal mobility and principal effectiveness (as measured by the estimated principal fixed effects) and in the relationship between principal experience and school performance. Eberts and Stone (1988) found a positive association between years of teaching experience and school performance. There is no significant difference in institutional effectiveness of schools with more and less age principals. Meaning thereby the age of school principals does not have significant effect on institutional effectiveness. The above finding is in tune with Lin (2000) investigating in the study that age did not have a significant correlation with school effectiveness as measured by student's academic achievement. there is no significant difference in institutional effectiveness of schools with more and less experience principals. Meaning thereby the experience of school principals does not have significant effect on institutional effectiveness. The above finding is in tune with Smith (2000) investigating in the study that years of experience had no effect on teacher perception of the principal's leadership style and Institutional Effectiveness. Ballou and Podgurskey (1993) found that there is no co-relation between year of experience and institutional effectiveness.

\section{REFERENCES}

Alm, S., Laftman, S. B., Sandahl, J., \& Modin, B. (2019). School effectiveness and students' future orientation: A multilevel analysis of upper secondary schools in Stockholm, Sweden. Journal of Adolescence, 70, $62-73$.

Anumaka, I. B. (2013). Institutional Effectiveness: Best Practices And Assessment Strategies In Uganda Universities. International journal of management, information technology and engineering, 1(2), 35-42.

Cerit, Y. (2009). The Effects of Servant Leadership Behaviours of School Principals on Teachers' Job Satisfaction. Educational Management Administration $\mathcal{E}$ Leadership, 37, 600-623. https:/ / doi.org/10.1177/1741143209339650

Erlendsson, J. (2002). Value For Money Studies in Higher Education. Retrieved from http://www.hi.is/ joner/eaps/wh_vfmhe.htmaccessed4 
Gasevic, D., Mirriahi, N., Dawson, S., \& Joksimovic, S. (2016). Effects of Instructional Conditions and Experience on the Adoption of a Learning Tool. Computers in Human Behavior, 43, 1-14.

Gupton, S. L. (2003). The instructional leadership toolbox: A handbook for improving practice. Thousand Oaks, CA: Corwin.

Hill, P. W. (2002). The principal challenge: Leading and managing schools in an era of accountability (M. S. Tucker \& J. B. Codding, Eds.). San Francisco: Jossey-Bass.

Huber, S. G. (2013). Multiple learning approaches in the professional development of school leaders-Theoretical perspectives and empirical findings on self assessment and feedback. Educational Management Administration \& Leadership, 41(4), 527-540.

Khan, A. (2012). Instructional Management of a Private and A Government Secondary School Principal in Northern Pakistan. International Journal of Educational Development, 32, 120-131.

Lin, H. C. (2000). A Study of Principals' Leadership Style and School Effectiveness in Selected Public Secondary Schools in New Jersey. Dissertation Abstract International-A, 60(0).

Martin, N. K., \& Sass, D. A. (2010). Construct Validation of the Behavior and Instructional Management Scale. Teaching and Teacher Education, 26, 1124-1135.

Pedersen, D., \& Hartley, J. (2008). The changing context of public leadership and management Implications for roles and dynamics. International Journal of Public Sector Management, 21(4), 327-339.

Sahu, B. (2002). New educational philosophy: Recent researchers in education and psychology. New Delhi: Sarup and Sons.

Saleem. (2012). Determinants Of School Effectiveness: A Study at Punjab Level. International Journal of Humanities and Social Science, 2(14), 242251.

Sass, D. A., Lopes, J., Oliveira, C., \& Martin, N. K. (2016). An Evaluation of the Behavior and Instructional Management Scale's Psychometric Properties using Portuguese Teachers. Teaching and Teacher Education, 55, 279-290.

Smith, J. M. (2000). Analysis of the Relationship Between Principal Leadership Style and Teacher Job Satisfaction. Dissertation Abstract International- $A, 61(1)$.

Southworth, G. (2002). Instructional leadership in schools: Reflections and empirical evidence. School Leadership \& Management, 22(1), 73-91.

Taiwo, A. E. (2015). Teacher Variables And School Effectiveness. International Journal of Humanities and Social Science, 5(7), 95-101.

Vlasceanu, L., Grunberg, L., \& Parlea, D. (2004). Quality Assurance and Accreditation: A Glossary of Basic Terms and Definitions (Bucharest, UNESCO-CEPES). 